\title{
KEDUDUKAN WAKIL MENTERI DALAM SISTEM \\ KETATANEGARAAN INDONESIA \\ PASCA PUTUSAN MAHKAMAH KONSTITUSI REPUBLIK INDONESIA \\ NOMOR 79/PUU-IX/2011
}

\author{
Novira Maharani Sukma ${ }^{1}$, Retno Saraswati $^{2}$
}

\begin{abstract}
Abstrak
Penelitian ini bertujuan untuk mendeskripsikan dan menganalisis pertimbangan dilaksanakannya pengangkatan wakil menteri dalam sistem ketatanegaraan Republik Indonesia, untuk mendeskripsikan dan menganalisis kedudukan wakil menteri pasca putusan Mahkamah Konstitusi Republik Indonesia Nomor 79/PUU-IX/2011, dan untuk mendeskripsikan dan menganalisis kedudukan wakil menteri pada masa yang akan datang. Metode penelitian yang digunakan dalam penelitian ini adalah yuridis normatif dengan menggunakan sumber data sekunder sebagai landasan pemikiran yang bersifat teoritis, kemudian data itu dianalisis secara deskriptif kualitatif. Berdasarkan hasil penelitian disimpulkan kedudukan Wakil Menteri pasca putusan Mahkamah Konstitusi Nomor 79/PUUIX/2011 apabila dilihat dari segi kewenangannya, kedudukan Wakil Menteri di bawah Presiden dan di bawah Menteri, karena Wakil Menteri bertanggungjawab kepada Menteri dan bertugas sebagai pembantu Menteri. Dari segipengangkatannya, kedudukan Wakil Menteri di bawah Presiden, sedangkan Menteri dan Wakil Menteri kedudukannya adalah sama, dikarenakan sama-sama diangkat dan diberhentikan oleh Presiden melalui tata cara dan prosedur yang sama, sedangkan Wakil Menteri kedudukannya di atas Sekretariat Jenderal/Sekretariat Kementerian. Kedudukan wakil menteri di masa yang akan datang sebaiknya ditiadakan saja, karena peraturan perundang-undangan yang mengatur wakil menteri telah diubah pasca putusan Mahkamah Konstitusi, namun belum mampu memberikan ketegasan mengenai pengaturan Wakil Menteri
\end{abstract}

Kata Kunci: Kedudukan Wakil Menteri, Sistem Ketatanegaraan Indonesia, Putusan MK

\footnotetext{
${ }^{1}$ Mahasiswa Program Studi Magister IImu Hukum UNDIP

${ }^{2}$ Dosen Program Studi Magister IImu Hukum UNDIP
} 


\begin{abstract}
The aims of the research are to describe and analyze the implementation considerations appointment of deputy ministers in the constitutional system of the Republic of Indonesia, to describe and analyze the position of deputy minister of post-verdict of the Constitutional Court of the Republic of Indonesia Number 79/PUU-IX/2011, and to describe and analyze the position of deputy minister in the future. The research methods used in Method normative approach, with secondary data source is used as a theoretical rationale, then the data were analyzed by descriptive qualitative. Based on the results of the study concluded Deputy Minister position after the Constitutional Court's decision 79/PUUIX/2011 when viewed in terms of its authority, the position of Deputy Minister under President and under the Minister, as the Deputy Minister is responsible to the Minister and served as assistant minister. Meanwhile, Deputy Minister of the Secretariat General / Secretariat of the Ministry of position can be said to be the same because both are equally as assistant minister. In terms of the position of Deputy Minister appointment under the President, while the Minister and Deputy Minister position is the same, because both appointed and dismissed by the President through the processes and procedures in the same, while the Deputy Secretary General of the Secretariat of the above position/Secretariat of the Ministry. The position of deputy minister in the future should be eliminated, because the legislation governing the deputy minister has been changed after the decision of the Constitutional Court, but has not been able to provide firmness on setting the Deputy Minister.
\end{abstract}

Keywords: The status of Deputy Minister, Indonesian constitutional system, Constitutional Court 
A. Latar Belakang

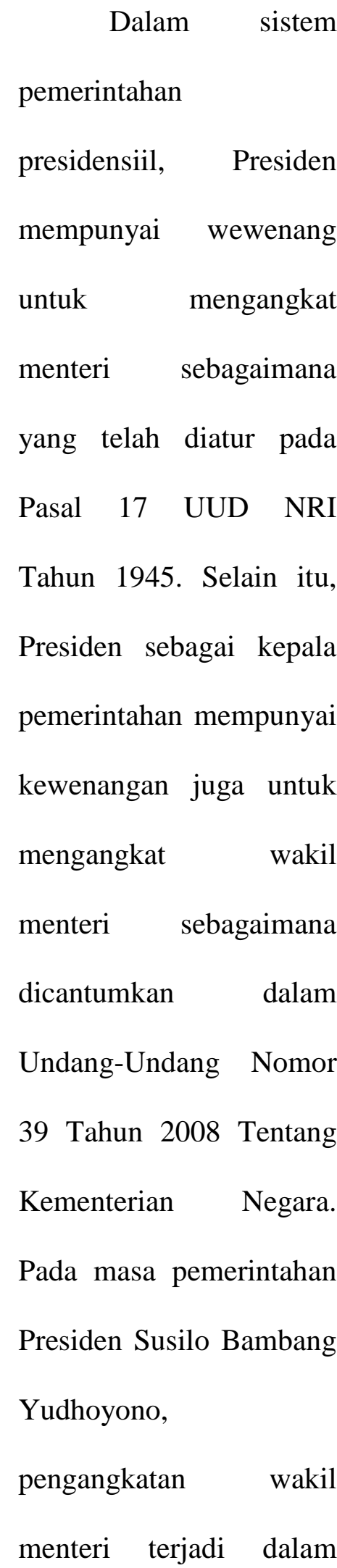

kabinet. Wakil Menteri

merupakan pejabat karier

dan bukan anggota

kabinet, berbeda dengan

menteri yang merupakan

jabatan politis. Wakil

Menteri dijabat oleh

pegawai negeri yang telah

menduduki jabatan

struktural eselon 1A. Hal

ini telah diatur pada

Penjelasan Pasal 10

Undang-Undang Nomor

39 Tahun 2008 .

Presiden

mengangkat Wakil

Menteri dalam rangka

menangani beban kerja

Kementerian yang

semakin berat dalam

melaksanakan tugas-tugas

pemerintah. Apabila

struktur yang baru

dibentuk tersebut (Wakil 


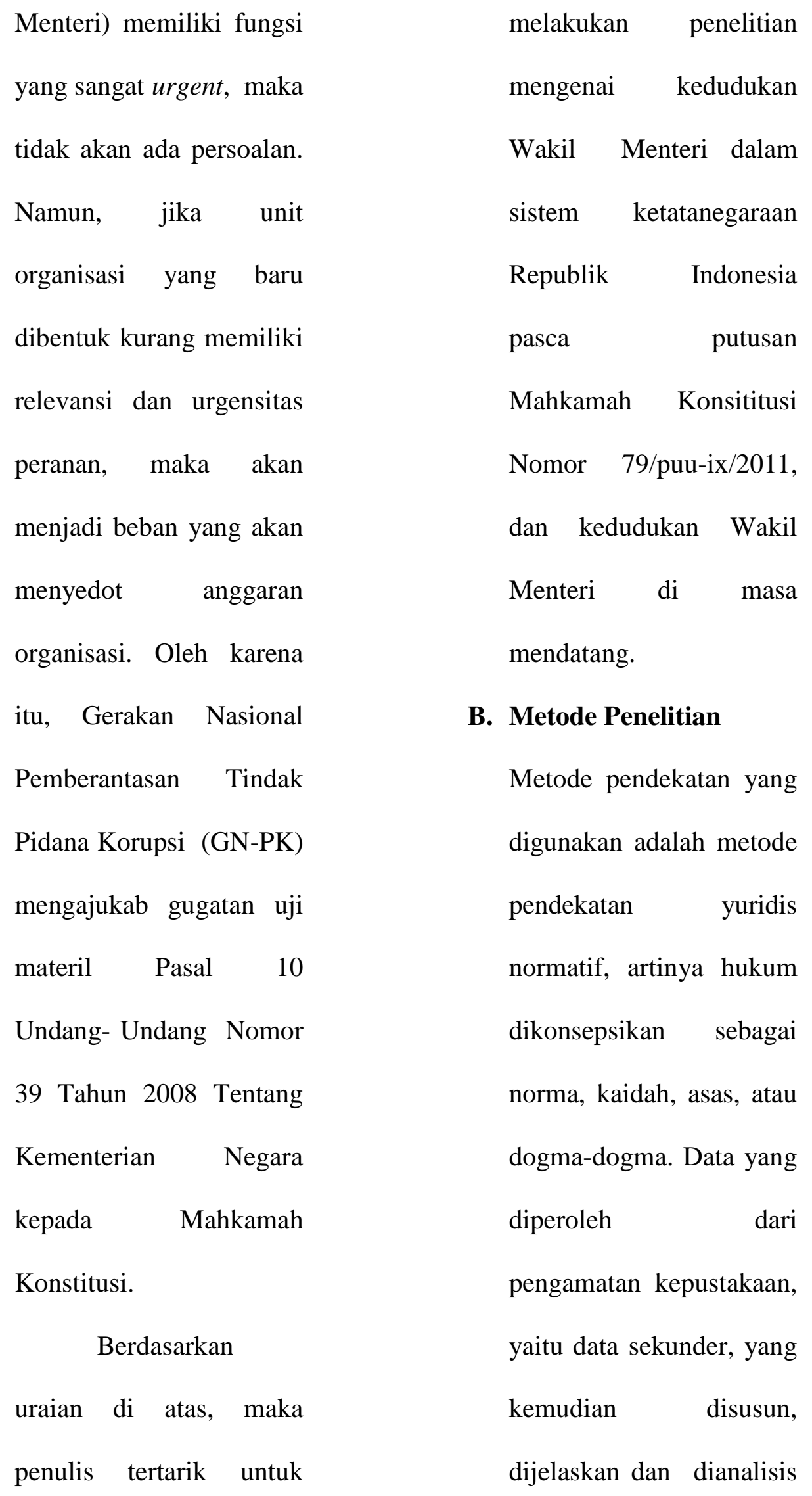




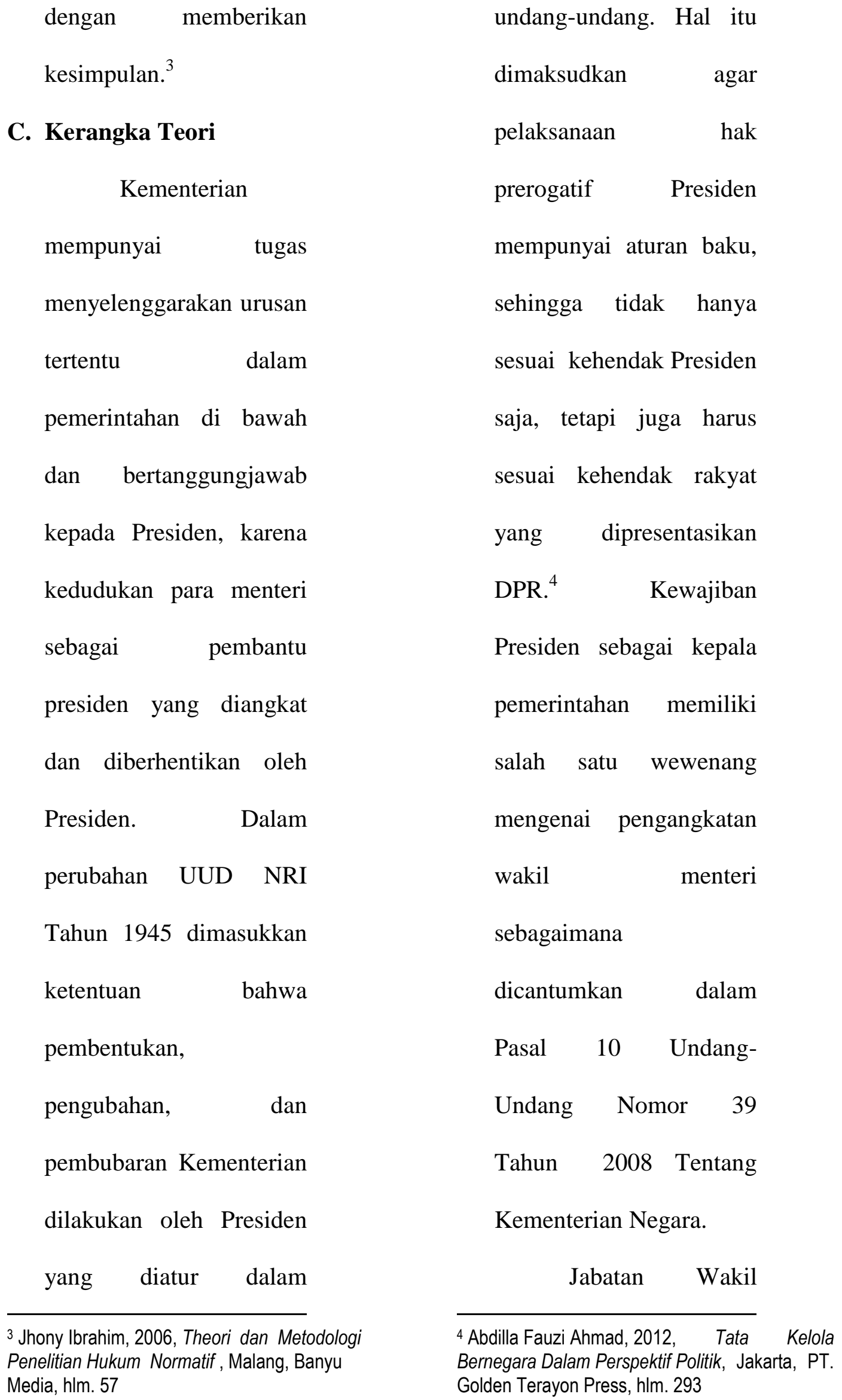




\begin{tabular}{|c|c|}
\hline Menteri adalah jabatan & kewenangan \\
\hline yang bersifat politis. & utama tetap berada di \\
\hline Dengan kata lain, wakil & tangan menteri. \\
\hline menteri diangkat oleh & Melalui kebijakan \\
\hline Presiden & ditetapkan \\
\hline mendampingi menteri & administrasi \\
\hline tertentu yang memiliki & negara, dalam hal ini \\
\hline beban tugas lebih, & Presiden, menimbulkan \\
\hline diharapkan & konsekuensi yang harus \\
\hline kementerian & dipenuhinya \\
\hline menjadi lebih efektif & pengangkatan \\
\hline dengan adanya wakil & wakil menteri. Negara \\
\hline menteri. Dilihat dari segi & menyediakan \\
\hline kewenangannya, jabatan & fasilitas-fasilitas khusus \\
\hline wakil menteri bukanlah & yang bersumber \\
\hline jabatan yang strategis. & anggaran pendapatan dan \\
\hline Wakil menteri hanya & belanja negara (APBN), \\
\hline berhak mewakili menteri & berupa rumah \\
\hline dan tidak punya hak & kendaraan dinas, biaya \\
\hline mengambil & operasional, \\
\hline serta hak suara dalam & tunjangan \\
\hline sidang-sidang & sekretaris, ajudan, staf \\
\hline Wakil menteri adalah & pembantu, supir, dan lain- \\
\hline subordinasi & lain, sedangkan anggar \\
\hline
\end{tabular}


tersebut

dapat

dipergunakan untuk

usaha-usaha yang bisa

membuka kesempatan

kerja, menambah biaya

pendidikan, dan untuk

meningkatkan taraf hidup

yang baik dan sehat, serta

pelayanan kesehatan

untuk warga negara.

D. Hasil dan Pembahasan

1. Pertimbangan

Pengangkatan

Wakil Menteri

Dalam

Sistem

Ketatanegaraan

Republik Indonesia

a. Pertimbangan

Filosofis

Berdasarkan

sejarah

ketatanegaraan

Indonesia yang telah disebutkan

dalam bahasan

sebelumnya,

posisi Wakil

Menteri pernah

diadakan, yaitu

pada era kabinet

presidensial

pertama pasca-

Proklamasi

Kemerdekaan 17

Agustus $\quad 1945$

(Periode

2

September-14

November 1945),

yakni Wakil

Menteri Dalam

Negeri dan Wakil

Menteri

Penerangan.

Padahal pada

masa tersebut

UUD 1945 masih

digunakan, karena 
Indonesia belum

masuk pada era

sistem

pemerintahan

parlementer

pertama yang

dipimpin oleh

Perdana Menteri

Sutan Syahrir.

\section{b. Pertimbangan}

\section{Hukum}

Landasan hukum

kementerian

adalah Bab V

Pasal 17 UUD

NRI Tahun 1945

menyebutkan

bahwa:

(1) Presiden

dibantu oleh

menteri-

menteri

negara.

(2) Menteri- menteri itu

diangkat dan

diperhentikan

oleh Presiden.

(3) Setiap

menteri

membidangi

urusan tertentu

dalam

pemerintahan.

(4) Pembentukan,

pengubahan,

dan

pembubaran

kementerian

negara diatur

dalam undang-

undang.

Dalam

menafsirkan dan

menjabarkan Pasal

17 UUD 1945

tidak semata-mata

melihatnya secara 


\begin{tabular}{|c|c|}
\hline eksplisit, tetapi & menteri pada \\
\hline perlu juga melalui & kementerian \\
\hline perspektif yang & tertentu \\
\hline lebih luas. Dalam & terdapat \\
\hline hal tidak diatur & kerja \\
\hline secara eksplisit, & membutuhkan \\
\hline tentunya presiden & penanganan secara \\
\hline dalam & khusus. Hal ini \\
\hline upaya & diatur pada Pasal \\
\hline menjalankan roda & Undang- \\
\hline pemerintahan & Undang Nomor 39 \\
\hline berdaya & Tahun \\
\hline guna dan berhasil & tentang \\
\hline guna harus pula & Kementerian \\
\hline diberi keleluasaan & Negara bahwa: \\
\hline untuk membentuk & "Dalam hal \\
\hline jabatan-jabatan & terdapat \\
\hline lain (jabatan wakil & beban kerja \\
\hline menteri) asal tidak & yang \\
\hline bertentangan & membutuhk \\
\hline dengan Pasal 17 & an \\
\hline sendiri. & penanganan \\
\hline Presiden & secara \\
\hline mengangkat wakil & khusus, \\
\hline
\end{tabular}


Presiden

kabinet"

dapat

mengangkat

wakil

menteri

pada

kementeria

n tertentu."

Penjelasan Pasal

10 Undang-

Undang Nomor 39

Tahun

2008

mengatakan

bahwa:

"Yang
dimaksud
"wakil
menteri"
adalah
pejabat
karier dan
bukan
merupakan
anggota

Diadakannya

jabatan Wakil

Menteri

merupakan upaya

untuk lebih

mengefektifkan

pemerintahan

presidensial,

terutama dikaitkan

dengan

berjalannya secara

baik visi, misi,

dan program yang

telah dijanjikan

Presiden sewaktu

kampanye Pemilu

dalam lingkup

kementerian

masing-masing,

tentu saja melalui

kerjasama dengan

Menteri yang

bersangkutan. 


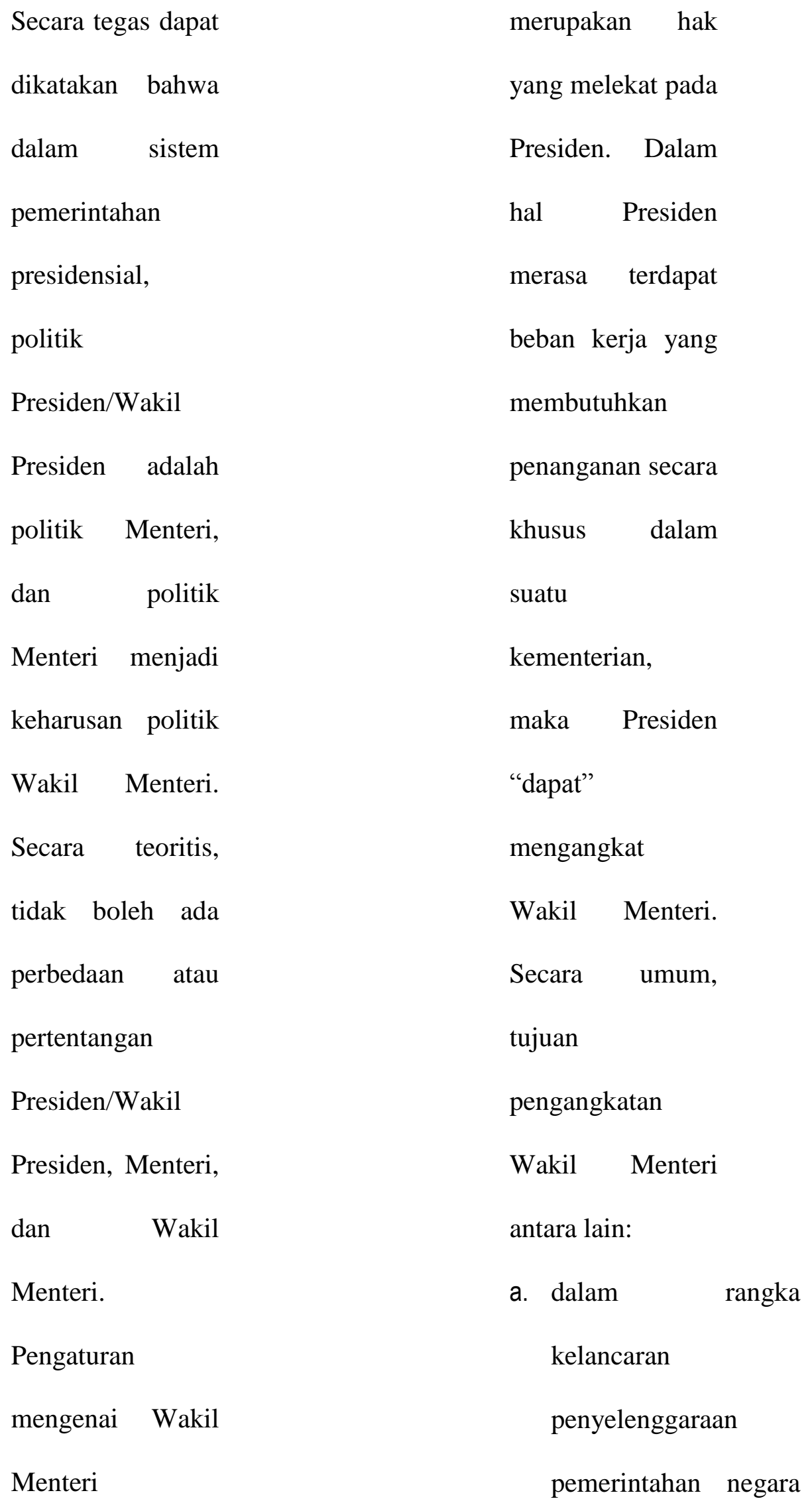


yang berdaya guna

dan berhasil guna;

b. untuk lebih

meningkatkan

efektifitas

pelaksanaan

tugas pokok

dan fungsi di

beberapa

kementerian

yang

membutuhkan

penanganan

secara khusus;

c. dalam rangka

menjamin

terwujudnya

tujuan dan

sasaran

tertentu yang

hendak dicapai

oleh suatu

kementerian.

\section{Kedudukan Wakil}

Pasca

Putusan Mahkamah

\section{Konstitusi Nomor}

79/PUU-IX/2011

Pada tanggal 5 juni

2012 Mahkamah Konstitusi

(MK) mengeluarkan putusan

Nomor $\quad 79 / P U U-I X / 2011$

yang intinya mengabulkan

sebagian permohonan

pengujian Pasal 10 Undang-

Undang Nomor 39 Tahun

2008 tentang Kementerian

Negara dengan membatalkan

penjelasan pasal tersebut.

Dalam putusannya, MK juga

menginstruksikan kepada

presiden untuk memperbarui

Keppres yang lama agar

sesuai dengan kewenangan

eksekutif dan tidak

menimbulkan ketidakpastian

hukum. Setelah adanya

putusan MK tersebut terjadi 
perubahan mengenai tatanan

dan struktur Wakil Menteri,

selain itu juga diakibatkan

oleh adanya beberapa

peraturan baru yang dibentuk

sebagai konsekwensi dari

putusan tersebut terkait

jabatan Wakil Menteri.

Penjelasan Pasal 10

Undang- Undang Nomor 39

Tahun 2008 tentang

Kementerian

Negara

dinyatakan tidak berlaku dan

tidak mempunyai kekuatan

hukum. Hal itu dikarenakan

tidak memenuhi syarat

formil ${ }^{5}$,

karena

menambahkan sebuah norma

baru yang sama sekali tidak

diperintahkan oleh norma

dasar.

5 Dalam arti formil yaitu dari segi prosedural dimana telah ditentukan syarat-syarat pembentukan peraturan perundangundangan. Baca Ahmad Syahrizal, 2006,

Peradilan Konstitusi, suatu studi tentang Adjudikasi Konstitusional sebagai Mekanisme Penyelesaian Sengketa Normatif, Jakarta, Pradya Paramita, hlm. 280.
Dengan

tidak

diberlakukannya

lagi

Penjelasan Pasal 10 Undang-

Undang Nomor 39 Tahun

2008 tentang Kementerian

Negara, maka secara

langsung mengubah tatanan

dan susunan Wakil Menteri

dengan dikeluarkannya

Peraturan Presiden Nomor 60

Tahun 2012 Tentang Wakil

Menteri yang mengatur

secara khusus mengenai hal-

hal yang menjadi

permasalahan dalam

Putusan Mahkamah

Konstitusi Nomor 79/PUU-

IX/2011. Selain itu,

Presiden juga memperbaiki

Keputusan Presiden

sebelumnya, yaitu melalui

Keputusan Presiden Nomor

65/M Tahun 2012 tentang

Perubahan Keputusan 
Presiden Nomor 111/M

Tahun 2009, Keputusan

Presiden Nomor 3/P Tahun

2010, Keputusan Presiden

Nomor 57/P Tahun 2010, dan

Keputusan Presiden Nomor

159/M Tahun 2011.

Putusan Mahkamah

Konstitusi (MK) yang

menyatakan bahwa posisi

Wakil Menteri diputuskan

konstitusional merupakan

bentuk penegasan dari

kewenangan penuh Presiden

dalam mengangkat Wakil

Menteri. Ke depannya,

Presiden bebas mengangkat

Wakil Menteri dari unsur

manapun dan tidak dibatasi

oleh ketentuan harus berasal

dari pejabat karir

sebagaimana

diatur

sebelumnya. Pasal 6

Peraturan Presiden Nomor 60
Tahun 2012 Tentang Wakil

Menteri disebutkan bahwa:

"Wakil Menteri dapat

berasal dari Pegawai Negeri

atau bukan Pegawai Negeri”.

Dengan demikian, maka dari

segi jabatannya sangat jelas

dan tegas bahwa Wakil

Menteri merupakan jabatan

karir dan non-karir. Namun,

dalam hal ini terdapat

ketimpangan, mengingat

jabatan Wakil Menteri

awalnya harus berasal dari

Pegawai Negeri Sipil, dan

pada saat ini diperbolehkan

berasal dari bukan Pegawai

Negeri Sipil. Bahkan, orang-

orang yang diangkat sebagai

Wakil Menteri rata-rata

berstatus Pegawai Negeri

Sipil. Dengan demikian, telah

terjadi politisasi pada

pengangkatan Wakil Menteri. 
Presiden dengan

kewenangannya,

mengeluarkan Perpres Nomor

60 Tahun 2012 tentang Wakil

Menteri, yang menempatkan

posisi Wakil Menteri tersebut

berada di bawah dan

bertanggung jawab kepada

Menteri (Pasal 1). Wakil

Menteri mempunyai tugas

membantu Menteri dalam

“memimpin" pelaksana tugas

Kementerian Negara (Pasal 2

ayat (1)). Tugas Wakil

Menteri adalah membantu

untuk "memimpin", maka

berdasarkan Pasal 2 ayat (1)

ini, Wakil Menteri

ditempatkan pada posisi

pimpinan, tetapi posisi

pimpinan di sini ditempatkan

pada "layer supporting to the

authority of the Minister". ${ }^{\circ}$

6 Bistok Simbolon, Kedudukan Wakil Menteri
Apabila dilihat dari

segi hak dan fasilitas

keuangan, memang Wakil

Menteri lebih tinggi dari

Pembantu Menteri,

Pengawas, dan Unsur

Pelaksana pada Kementerian

tertentu. Wakil Menteri

mendapat hak keuangan dan

fasilitas lainnya bagi Menteri

dan di atas jabatan struktural

eselon 1, sehingga lebih

tinggi dari pejabat di bawah

Menteri semuanya. Meskipun

dalam hak keuangan dan

fasilitas lainnya lebih tinggi

dari jabatan lain di bawah

Menteri, namun Wakil

Menteri tidak dimasukkan

dalam struktur organisasi

Kementerian Negara

sehingga menimbulkan

kerancuan dalam tataran 
penerapan struktur organisasi.

Hal itu tentu sangat berkaitan

dengan koordinasi dan

komunikasi antar pejabat

struktural pada Kementerian

tertentu. Ke depannya perlu

harmonisasi pengaturan

mengenai posisi dan

kedudukan Wakil Menteri

dalam susunan organisasi

Kementerian Negara.

Mengenai hak keuangan dan

fasilitas yang didapat oleh

Wakil Menteri diatur melalui

Peraturan Menteri Keuangan

Republik Indonesia Nomor

164/PMK.02/2012 tentang

hak keuangan dan fasilitas

lainnya bagi Wakil Menteri.

Terkait dengan

jabatan wakil menteri, telah

diatur pada Pasal 4 ayat (2)

Peraturan Presiden Nomor 60

Tahun 2012 Tentang Wakil
Menteri disebutkan bahwa:

"Masa jabatan Wakil Menteri

paling lama sama dengan

masa jabatan atau berakhir

bersamaan dengan

berakhirnya masa jabatan

Presiden yang

bersangkutan". Selain itu,

dipertegas pula dalam

Keputusan Presiden Nomor

65/M Tahun 2012 tentang

Perubahan Keputusan

Presiden Nomor 111/M

Tahun 2009, Keputusan

Presiden Nomor 3/P Tahun

2010, Keputusan Presiden

Nomor 57/P Tahun 2010, dan

Keputusan Presiden Nomor

159/M Tahun 2011 yang di

dalamnya juga menyebutkan

mengenai masa jabatan

Wakil Menteri adalah "masa

jabatan paling lama sama

dengan masa jabatan atau 
berakhir bersamaan dengan

berakhirnya masa jabatan

Presiden periode 2009-

2014". Dengan demikian,

jelaslah bahwa masa jabatan

Wakil Menteri sama dengan

masa jabatan Presiden dan

Menteri.

Mahkamah Konstitusi dalam

pendapatnya dengan akurat

membangun suatu konstruksi

berpikir yang sistemik tentang

kedudukan Presiden dalam sistem

Pemerintahan berdasarkan UUD

1945. Presiden adalah pemegang

kekuasaan pemerintahan menurut

Pasal 4 ayat (1) dan Pasal 17 ayat

(1) dan ayat (2) UUD NRI Tahun

1945. Bertolak dari Pasal 4 ayat

(1) dan Pasal 17 ayat (2) UUD

1945 tersebut, MK sampai pada

pendapat bahwa pengangkatan

Wamen adalah bagian dari

kewenangan Presiden untuk melaksanakan tugas-tugasnya, baik diatur maupun tidak diatur dengan UU. Pengangkatan Wakil menteri sebenarnya merupakan bagian dari kewenangan Presiden, sehingga dari sudut substansi tidak terdapat persoalan konstitusionalitas dalam konteks ini. Pendapat MK tersebut membuat terang hak konstitusional Presiden untuk mengangkat Wakil Menteri, sekalipun tidak ada UU yang mengaturnya, bahkan sekalipun ada uji materi terhadap UU Kementerian Negara.

$$
\text { Berdasarkan amanat dari }
$$

putusan MK yang menginstruksikan Presiden untuk membuat Peraturan Presiden (Perpres) yang mengatur tentang Wakil Menteri, maka diterbitkanlah Perpres Nomor 60 Tahun 2012 tentang Wakil 


\begin{tabular}{|c|c|}
\hline Menteri. Tugas-tugas & khusus, bukan menjalankan tugas- \\
\hline Menteri menurut Perpres Nomor & tugas yang begitu luas yang ada \\
\hline 60 Tahun 2012, sangat lah luas, & dalam Perpres Nomor 60 Tahun \\
\hline namun jika mengacu pada pasal & 2012 tersebut. \\
\hline 10 Undang-Undang Nomor 39 & Sebenarnya, tidak terjadi \\
\hline Tahun 2008, hal ini terlihat & perubahan \\
\hline bertentangan. Dalam Pasal 10 & antara tugas dan wewenang \\
\hline disebutkan bahwa "Dalam hal & Wakil Menteri sebelum dan \\
\hline terdapat beban kerja yang & sesudah \\
\hline membutuhkan penanganan secara & Mahkamah Konstitusi Nomor \\
\hline khusus, presiden & 79/PUU-IX/2011, hanya \\
\hline mengangkat Wakil Menteri”. & dalam Peraturan Presiden Nomor \\
\hline Dari pasal di atas dapat dilihat & 91 Tahun 2011 tentang Perubahan \\
\hline bahwa Wakil Menteri merupakan & Ketiga Peraturan Presiden Nomor \\
\hline sebuah jabatan optional dimana & tentang \\
\hline jika di suatu Kementerian tertentu & Pembentukan dan Organisasi \\
\hline memiliki beban kerja yang berat, & Kementerian Negara, rincian \\
\hline maka di saat itulah keberadaan & tugas Wakil Menteri yang belum \\
\hline Wakil Menteri diperlukan. Selain & diatur dalam Peraturan Presiden \\
\hline itu, dalam Pasal 10 juga & Nomor 91 Tahun 2011 tentang \\
\hline mengisyaratkan bahwa Wakil & Perubahan \\
\hline Menteri hanya berwenang untuk & Presiden Nomor 47 Tahun 2009 \\
\hline mengerjakan beban kerja yang & Pembentukan \\
\hline membutuhkan penanganan & Organisasi Kementerian Negara \\
\hline
\end{tabular}


tersebut, dapat diatur lebih lanjut

oleh masing-masing Menteri yang

bersangkutan.

3. Kedudukan

Wakil

Menteri di Masa yang

Akan Datang

Menurut

Penulis,

kedudukan Wakil Menteri di

masa yang akan datang

sebaiknya ditiadakan, karena

terdapat beberapa permasalahan

yang timbul dengan adanya

jabatan Wakil Menteri. Seperti

yang telah dibahas sebelumnya,

bahwa dalam Undang-Undang

Nomor 39 Tahun 2008 tentang

Kementerian Negara tidak diatur

mengenai golongan dan

kepangkatan Wakil Menteri.

Selanjutnya, dalam Peraturan

Presiden Nomor 47 Tahun 2009

tentang Pembentukan dan

Organisasi Kementerian Negara

yaitu dalam Pasal 91 juncto Pasal
70A Peraturan Presiden Nomor

76 Tahun 2011 tentang

Perubahan Atas Peraturan

Presiden Nomor 47 Tahun 2009

tentang Pembentukan dan

Organisasi Kementerian Negara

menyatakan bahwa golongan

dan kepangkatan Wakil Menteri

adalah setara dengan jabatan

struktural eselon 1a. Kemudian

berdasarkan Pasal 70B

Peraturan Presiden Nomor 91

Tahun 2011 tentang Perubahan

Ketiga Peraturan Presiden

Nomor 47 Tahun 2009 tentang

Pembentukan dan Organisasi

Kementerian Negara juncto Pasal

5 ayat (1) dan ayat (2) Peraturan

Presiden Nomor 60 Tahun 2012

tentang Wakil Menteri, golongan

dan kepangkatan Wakil Menteri

adalah di atas jabatan struktural

eselon la. Hal ini tentunya

menimbulkan persoalan 
tersendiri, karena Peraturan

Pemerintah Nomor 100 Tahun

2000 tentang Pengangkatan

Pegawai Negeri Sipil Dalam

Jabatan Struktural juncto

Peraturan Pemerintah Nomor 13

Tahun 2002 tentang Perubahan

Atas Peraturan Pemerintah

Nomor 100 Tahun 2000 tentang

Pengangkatan Pegawai Negeri

Sipil Dalam Jabatan Struktural,

menyatakan bahwa eselon

tertinggi adalah Eselon 1a

dengan pangkat terendah

Pembina Utama Madya golongan

IVD dan tertinggi pangkat

Pembina Utama dengan

golongan IVE, sehingga apabila

dikatakan bahwa golongan dan

kepangkatan Wakil Menteri

adalah di atas jabatan

struktural eselon la, maka

Golongan dan kepangkatan

Wakil Menteri merupakan golongan dan kepangkatan yang baru dan sama sekali tidak ada dalam hukum kepegawaian.

Selain itu, masalah lain yang timbul adalah pengeluaran anggaran negara untuk membiayai Wakil Menteri sangat besar, seperti jaminan kesehatan, rumah dinas, kendaraan dinas, dan tunjangan-tunjangan lainnya. Dilihat dari segi kewenangan dan urgensinya, pengangkatan Wakil Menteri tidak sesuai dengan semangat untuk mengurangi pengeluaran Keuangan Negara, seperti yang diusahakan dalam pembatasan rekrutmen Pegawai Negeri Sipil, yang salah satu alasannya adalah mengurangi beban anggaran Negara untuk membayar pegawai. Selain itu, semangat efesiensi dan efektifitas dalam pembentukan Kementerian tidak tercapai, 


\begin{tabular}{|c|c|}
\hline sebagaimana yang dimaksud & menimbulkan \\
\hline pada Pasal 13 ayat (2) Undang- & mengingat Wakil menteri adalah \\
\hline Undang Nomor 39 Tahun 2008 & lembaga yang bersifat baru dan \\
\hline tentang Kementerian Negara. & dibentuk langsung oleh Presiden, \\
\hline Terjadi inkonsistensi terhadap & akan tetapi memiliki kewenangan \\
\hline pembentukan & yang sama atau lebih besar dari \\
\hline Negara yang salah satu faktornya & Kementerian, \\
\hline adalah efisiensi dan efektivitas. & sehingga hal ini dapat \\
\hline Kedudukan Wakil Menteri yang & menimbulkan \\
\hline ada pada saat ini, jika dikaitkan & kemudan hari, mengingat peran \\
\hline dengan anggaran & dan fungsi Wakil Menteri \\
\hline dikeluarkan untuk kebutuhan & sebelumnya memang \\
\hline Wakil Menteri sangat tidak & dilaksanakan oleh Sekretariat \\
\hline efisien dan efektif. & Kementerian. \\
\hline Apabila dikaji secara & dengan adanya lembaga baru \\
\hline seksama, terdapat beberapa & yang dibentuk oleh Presiden, \\
\hline kewenangan Wakil Menteri yang & kewenangan tersebut diberikan \\
\hline juga menjadi kewenangan & kepada Wakil Menteri. Beberapa \\
\hline Sekretariat Kementerian. Oleh & kewenangan Wakil Menteri yang \\
\hline karena itu, dimungkinkan terjadi & diberikan \\
\hline konflik kewenangan & Sekretariat \\
\hline Menteri & Sekretariat Kementerian telah \\
\hline Sekretariat Kementerian. Selain & diatur dalam Peraturan Presiden \\
\hline itu, dalam tataran praktis & Nomor 47 Tahun 2009 tentang \\
\hline
\end{tabular}


Pembentukan dan Organisasi

Kementerian Negara.

Apabila terjadi konflik

kewenangan antara Sekretariat

Kementerian atau Sekretariat

Jenderal dengan Wakil Menteri,

maka ada beberapa cara yang

dapat ditempuh untuk

meminimalisir kemungkinan

sengketa kewenangan antara

Sekretariat Kementerian atau

Sekretariat Jenderal dengan Wakil

Menteri, yaitu dengan

diadakannya rapat dan koordinasi

pembagian kewenangan antar

Sekretariat Kementerian dengan

Wakil Menteri, dengan demikian

terjadi kesinambungan

kewenangan secara harmonis.

Sedangkan, cara lain yang dapat

ditempuh yaitu meminta saran

dan petunjuk dari Menteri

mengenai pembagian ruang

lingkup tugas, fungsi, dan wewenang, sehingga tercipta

harmonisasi kewenangan dalam

struktur organisasi Kementerian.

\section{E. Simpulan}

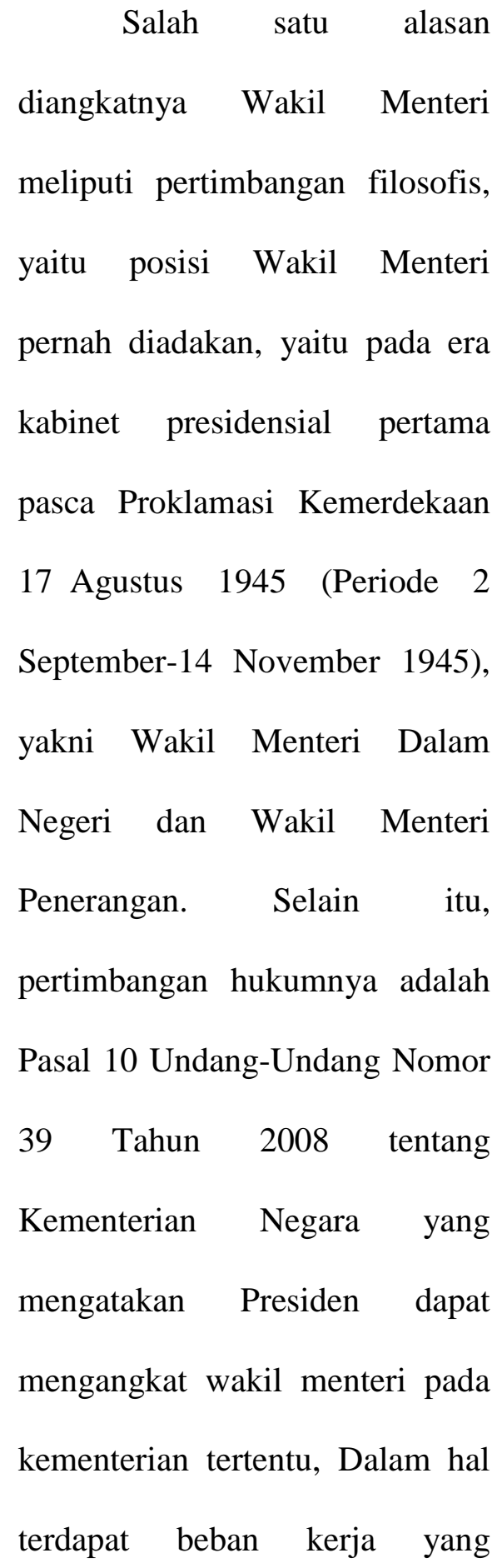


membutuhkan penanganan secara khusus.

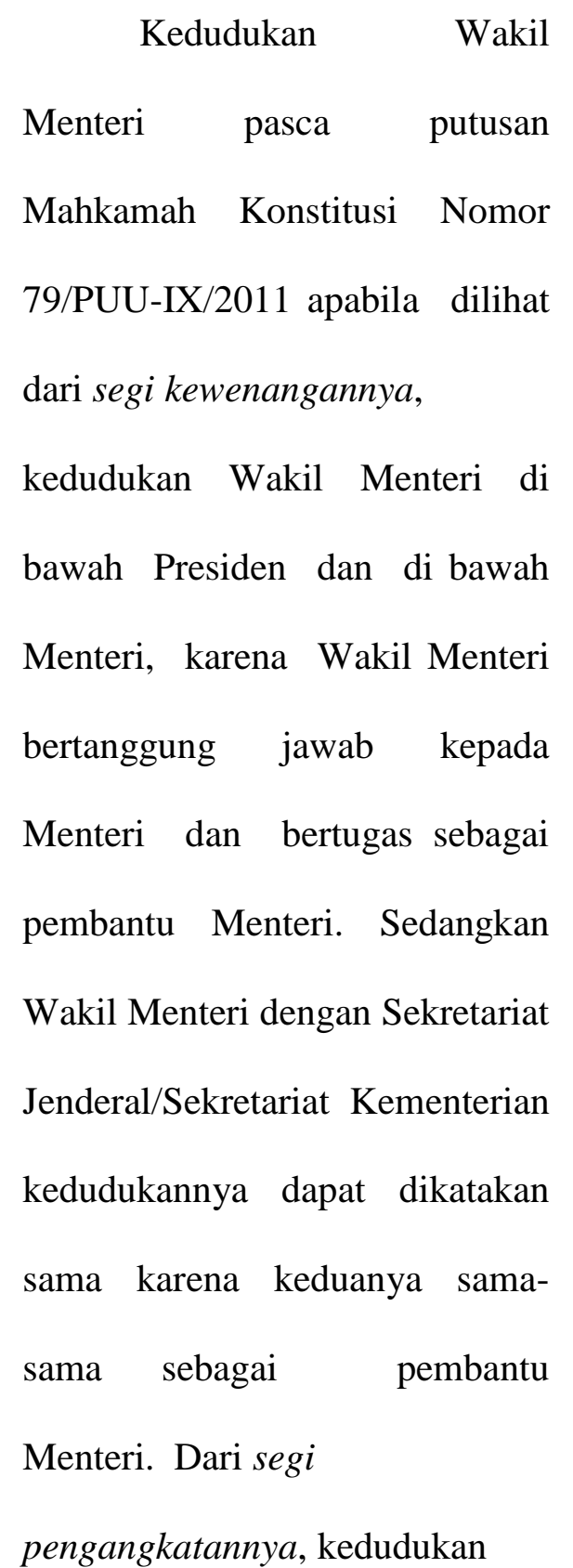

Wakil Menteri di bawah

Presiden, sedangkan Menteri

dan Wakil Menteri

kedudukannya adalah sama, dikarenakan

sama-sama

diangkat dan diberhentikan oleh

Presiden melalui tata cara dan

prosedur yang sama, sedangkan

Wakil Menteri kedudukannya

diatas

Sekretariat

Jenderal/Sekretariat Kementerian.

Dari segi struktur

organisasi, kedudukan Wakil

Menteri tidak dijelaskan secara

normatif dalam peraturan

perundang-undangan, meskipun

dalam prakteknya Wakil Menteri

berada di bawah Menteri dan di

atas

Sekretariat

Jenderal/Sekretariat

Kementerian.Jabatan Wakil

Menteri pasca putusan

merupakan jabatan karier atau

non karier. Kedudukan wakil

menteri di masa yang akan

datang sebaiknya ditiadakan saja,

karena peraturan perundang- 
undangan yang mengatur wakil

menteri telah diubah pasca

putusan Mahkamah Konstitusi

Nomor 79/PUU-IX/2011 namun

belum mampu memberikan

ketegasan mengenai pengaturan

Wakil Menteri.

\section{Daftar Pustaka}

Ahmad, Abdilla Fauzi, 2012, Tata Kelola Bernegara Dalam Perspektif Politik, Jakarta: PT.Golden Terayon Press

Jhony Ibrahim, 2006, Theori dan Metodologi Penelitian Hukum Normatif, Malang: Banyu Media

Syahrizal, Ahmad, 2006, Peradilan

Konstitusi (Suatu studi tentang Adjudikasi

Konstitusional sebagai Mekanisme Penyelesaian Sengketa Normatif), Jakarta: Pradya Paramita

\section{Peraturan perundang-undangan:}

Undang-Undang Dasar Negara Republik Indonesia Tahun 1945

Undang-Undang 39 Tahun 2008 Tentang Kementerian Negara

Peraturan Presiden RI Nomor 47 Tahun $2009 \quad$ Tentang Pembentukan dan Organisasi Kementerian Negara
Peraturan Presiden RI Nomor 76 Tahun $2011 \quad$ Tentang Perubahan Atas Peraturan Presiden RI Nomor 47 Tahun $2009 \quad$ Tentang Pembentukan dan Organisasi Kementerian Negara

Peraturan Presiden RI Nomor 77 Tahun $2011 \quad$ Tentang Perubahan Kedua Peraturan Presiden RI Nomor 47 Tahun $2009 \quad$ Tentang Pembentukan dan Organisasi Kementerian Negara

Peraturan Presiden RI Nomor 91 Tahun $2011 \quad$ Tentang Perubahan Ketiga Peraturan Presiden RI Nomor 47 Tahun $2009 \quad$ Tentang Pembentukan dan Organisasi Kementerian Negara

Peraturan Presiden Nomor 60 Tahun 2012 Tentang Wakil Menteri Keputusan Presiden Nomor 111/M Tahun 2009

Keputusan Presiden Nomor 3/P Tahun 2010

Keputusan Presiden Nomor 57/P Tahun 2010

Keputusan Presiden Nomor 159/M Tahun 2011

Keputusan Presiden Nomor 65/M Tahun 2012 tentang Perubahan Keputusan Presiden Nomor 111/M Tahun 2009

Peraturan Menteri Keuangan

Nomor 36/PMK.02/2011 tentang Pelaksanaan 


$$
\begin{aligned}
& \text { dan Jaminan } \\
& \text { Pemeliharaan } \\
& \text { Kesehatan Menteri } \\
& \text { dan Pejabat Tertentu }
\end{aligned}
$$

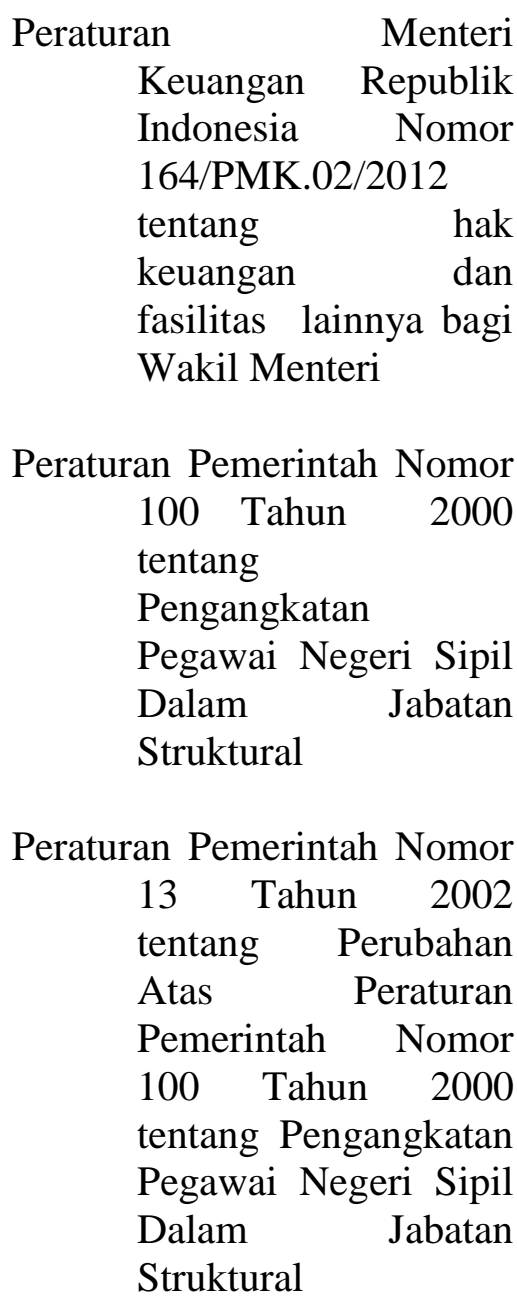

Putusan Mahkamah Konstitusi Nomor Nomor 79/PUUIX/2011

\section{Website:}

Bistok Simbolon, Kedudukan Wakil Menteri Cukup Jelas, <http://setkab.go.id/artikel4689-.html>, diakses pada tanggal 30 Juni 2011 